\title{
IMPACT OF UTILITARIAN AND HEDONIC ONLINE SHOPPING VALUE ON WOMAN CUSTOMER PERCEIVED VALUE IN SITE LAZADA
}

\author{
$1^{\text {st }}$ Shinta Wahyu Hati \\ Departemen of Business Management \\ Politeknik Negeri Batam \\ Batam, Indonesia \\ shinta@polibatam.ac.id
}

\author{
$2^{\text {nd }}$ Widi Putri Utami \\ Departemen of Business Management \\ Politeknik Negeri Batam \\ Batam, Indonesia \\ widiputrinasution@gmail.com
}

\begin{abstract}
This study to determine the effect of the value of the internet shopping which is utilitarian value and hedonic value of the perceived value or perceived value to the female customers on fashion products on the site Lazada Indonesia for the creation of repurchase (repurchase intention). Respondents in this study are women in Batam whoever shopped online on the site Lazada Indonesia. The technique of collecting data is using questionnaires which is distributed online that aims to shorten the time due to a large enough number of respondents as many as 300 respondents. Test instruments research are using validity and reliability. Methods of data analysis used in this research is descriptive and Partial Least Square (PLS). The analytical tool is used to determine the extent of utilitarian value (X1) and hedonic value (X2) will affect the perceived value (Y) either partially or simultaneously on female customers in fashion products on the site Lazada. These results indicate that both partial and variables simultaneously utilitarian value (X1) and hedonic value $(X 2)$ positive and significant impact on the perceived value $(\mathrm{Y})$
\end{abstract}

Keywords - Shopping Center, utilitarian value, hedonic value, Repurchase

\section{INTRODUCTION}

Chairman of Indonesia E-commerce Association (IDEA), Aulia E.Marinto said, Indonesia is currently the country with the highest growth of e-commerce in the world. In recent years, more and more businesses, both large enterprises as well as retail, switch or expand a business towards digital is to shop online. The e-commerce number will continue to grow; it is reinforced by a number of survey information and communications technology research institutes at home and abroad [1]

Based on the survey results and report on progress in the online shop or online store in Indonesia by Indonesian Internet Service Provider Association in 2016 states that commercial content that is frequently visited by Internet users is $62 \%$ with a total of 82.2 million people are content online shop, business personal amounted to $34.2 \%$ with a total of 45.3 million inhabitants and $3.8 \%$ more for a total of 5 million inhabitants.

Lazada.co.id is an example of a retail site that sells a wide range of needs such as: electronics, vouchers, home appliances, beauty to fashion. On Brand award TOP Lazada 2017 ranked second in the category TOP fashion products[2]. Lazada success also lies in the purchasing process for consumers that are on fashion products which form the basis in this case study. Because it can be known fashion product is also available on other online sites so competition is getting bigger customers.

In the online shop, there are many media used in online transactions. Whether it's through web sites, mobile applications, social, and other tissues, causing the increasingly fierce competition in getting customers. With a wide range of range of products offered in the online shop like fashion which was ranked top in e-commerce products are the most sought after [3].

In marketing fashion products, women made as a main target in the sale of fashion products. In the course of a study conducted by Kraft and Michael [4] entitled "A Look at Gender Differences and Marketing Implication" says that men and women have different purchasing decisions and around $85 \%$ are in women's purchase decisions.

Based on data from the Central Statistics Agency of Batam 2014 the number of women registered as workers in Batam amounting to 141728 workers with different types of jobs. Surely it is, makes women in Batam city only has a short time to buy their needs. Thus, the online store has become one alternative in providing efficient shopping to meet their needs.

Consumer perceived value can be formed by motivational value of the internet shopping (utilitarian and hedonic). Based on this, the online businesses need to identify the factors that internet shopping motivation (utilitarian and hedonic) online through customer perceived value (perceived value).

In this study, researchers analyzed two motivational variables shopping on the Internet, namely, utilitarian and hedonic value which will affect the perceived value. The use of these variables is based on previous research conducted by [5] which showed significant results in the utilitarian and hedonic on perceived value and in the course of a study also draws on research conducted by $\mathrm{Kim}, \mathrm{Xu}$, and Gupta [6] which showed significant results that trust and price may be used as one of the dimensions of the value of the internet shopping (utilitarian and hedonic) which has a positive effect on perceived value

\section{LITERATURE REVIEW}

\section{A. Motivation Shopping}

Motif consumer spending in Retail Management at [7] is a state in the person of someone who encourages the desire 
of individuals to perform certain activities. Motif is inside someone will awaken and realize a behavior that is aimed to achieve the goals and objectives of satisfaction. In the role directly, motif has several important functions to direct the consumer is as follows,

a. Primary motive

A motif that causes the selection of the general category of a product to certain category.

b. Motif selective

A motive that influence decisions regarding the selection of the model and brand of first-class product.

c. Rational motive

A motif based on the fact as directed by a product to consumers. Shopping rational attitude is influenced by rational reasons in one's mind of consumers. How to think someone can be so strong that the consumer makes such a feeling of prestige to be very small and lost.

d. Emotional motives

A motive that led to the selection related to individual feelings or one's past experiences. Emotional motivation is motivation that influenced the emotions associated with feelings, be it beauty, prestige, or other emotions, including compassion and anger, beautiful or good factor

\section{B. Shopping Decisions}

Customer shopping behavior pattern changes and developments in line with changing consumer wants and needs. Customer shopping process or stage begins when customers recognize a need that is not satisfied. Then, the customer will be looking for information on how to meet these needs [7]

\section{Value Shopping Center}

Shopping activity was originally made by the consumer in a rational way, namely with regard to the benefits provided such products (utilitarian value). However, this time spending activity is also influenced by the emotional values such as enjoyment and pleasure, or known as hedonic value (hedonic value) [8][9]. Motivational value of consumer spending (Customer Shopping Motivation) consists of two that is utilitarian and hedonic shopping will be explained as follows:

\section{A. Utilitarian Shopping Value}

Consumer behavior oriented utilitarian value will choose the products efficiently, based on a rational reason [11]. Value and utilitarian shopping motives can be characterized as a decision based on critical thinking, rational, effective decisions, goal-oriented, and affect customer satisfaction. Utilitarian internet buyers would prefer to focus on specific functions, such as the evaluation of the product and price comparison features in the design before buying. As based on previous research conducted by [12] categorize utilitarian value to two dimensions: efficiency (efficiency) and achievement (achievement).

\section{B. Hedonic Shopping Value}

Hedonic value is the value of selecting quality shopping environments in terms of pleasure (enjoyment) are perceived, being interested as a result of the eye (visual appeal) and relief (escapism) [12]. Meanwhile, [13] Hedonic Shopping categorize the value to 6 dimensions of adventure shopping, social shopping, shopping gratification, value shopping, shopping ideas, and the role of shopping.

C. Perceived Value

Values were considered customer (customer perceived value) is the difference between the evaluation of prospective customers all the benefits and all the costs of certain bids and other alternatives are considered [14]. Perceived value on each person is different because it is motivated by the norms in the family, the environment, life goals, ideals, and so forth [13].

Then it can be concluded that the value of the customer thinks (perceived value) based on the difference obtained by the customer with what is given or offered earlier. Potential customers will exercise discretion before purchasing is by way of assessing a product or brand that provides a variety of options. The higher the value obtained, the more positive is also perceived value of a product to be purchased. Conversely, if the lower value obtained, the more negative is also perceived value of the product to be purchased. Positive and negative results showed that the product is considered as expected and perceived not as expected.

Based on previous research conducted [6], entitled "Which is More Important in Internet Shopping, Perceived Price or Trust?" Shows the significant results that trust and prices as the dimensions of the value of the internet shopping (utilitarian and hedonic) positive effect on the perceived value that these dimensions can be made measurements on perceived value.

\section{RESEARCH METHODS}

\section{Population and Sample}

In this study does not use the entire population but uses a sample that is part of the number and characteristics possessed by this population. When large populations and research impossible to learn all there is in the population, for example, because of limited funds, manpower, time, research can use the sample drawn from the population. Based on the description of the sampling method in this study is nonprobability sampling with purposive sampling technique with the following criteria:

a. Women in Batam

b. Active shopping fashion products on the site Lazada

c. At least 17 years

In partial least square (PLS) is a minimum sample size of 35-50 [16]. Meanwhile, a decent sample size in the study was between 30 to 500 [14]. As well as the large sample size> 250 can increase the accuracy and consistency of the estimation results of SEM PLS [14]. Therefore, the authors determine the amount of the sample to 300 respondents. The sampling technique is used by distributing questionnaires to the respondents through an online questionnaire so that the writer is easier to reach the answers of the respondents.

\section{Validity and Reliability}

A. Validity: Validity test used to measure whether a legitimate or valid questionnaires. A questionnaire considered valid if the question or statement on the questionnaire were able to uncover something that will 
be measured by the questionnaire [16]. Prior to processing the data, it is necessary to test the data on these variables. Validity test can indicate the extent to which the tool can be measured. In this study, the authors use a PLS (Partial Least Square) which can be seen in testing the validity of the outer analysis models.

B. Convergent Validity, Convergen validity value is the value of the loading factor on the latent variables with their indicators.

C. Discriminant Validity, This value is the value of cross loading factor that is useful to know whether the construct has adequate discriminant that is by comparing the value of the loading on the intended constructs must be greater than the value of the loading with the other constructs.

D. Average Variance Extracted (AVE).

E. Reliability, Reliability is a tool to measure a questionnaire which is an indicator of variables or constructs. Reliability testing instrument aims to determine the consistency of an instrument. A questionnaire said to be reliable or reliable if someone answers on the statement is consistent or stable over time [16].

\section{Inferential Statistics}

\section{A. Designing Measurement Model (Outer Model)}

Outer Analysis Model referred to as the outer relations or measurement model that defines how each block of indicators associated with latent variables. Outer model is a measurement model to test the validity and reliability [16] The measurement results obtained from the process of iteration algorithms are derived from measurements (convergent validity, discriminant validity, composite reability and Crobach 's Alpha).

Convergent validity can be seen from the correlation between the scores of indicators with a score of variables. The size of individual reflexive said to be high if more than 0.7 correlated with the construct to be measured even if the value of 0.6 is said to be sufficient loading[16]

\section{B. Designing a Structural Model (Inner Model)}

Structural models evaluated using the formula R-square for the dependent variable, Q-square test for predictive relevance. When the $\mathrm{R}$-square value is greater than 0.2 , it can be interpreted that the latent predictor has great influence on the structural level. If the R-square PLS model can be evaluated with predictive relevance to construct the model, then the Q-square measure how well the observed values generated by the model and estimation parameters. Q-square value greater than 0 (zero) shows that the model lacks predictive relevance. However, if the results show a greater than 0 (zero), then the model is feasible is said to have the relevant predictive value [16].

\section{Hypothesis testing}

Explanatory method research approach is a method that can be operated by using PLS. Hypothesis testing using ttest is used to see the effect of partially and $f$ test to see the effects simultaneously. As for the explanation as follows:

1. $t$ test

Hypothesis testing using $\mathrm{t}$ test can be seen using the statistical values for the alpha $5 \%$ and the value of t-statistic used is 1.96. So that the criteria for acceptance or rejection hypothesis is as follows:

a. If the t-statistic value is smaller than t-table [t-statistic $<1.96]$, then, H1 rejected.

b. If the value of t-statistic greater than or equal to the value of the t-table [t-statistic $\geqslant 1.96$ ], then, $\mathrm{H} 1$ accepted.

2. test $F$

Testing the hypothesis by using test $\mathrm{f}$ serves simultaneously to see the relationship between independent variables with the dependent variable.

\section{RESULT AND DISCUSSION}

\section{A. Designing Measurement Model (Outer Model)}

Outer Analysis Model referred to as the outer relations or measurement model that defines how each block of indicators associated with latent variables. Outer model is a measurement model to test the validity and reliability [16]. The measurements obtained from the process of iteration algorithms are derived from measurements (convergent validity, discriminant validity, composite reability and Cronbach's Alpha).

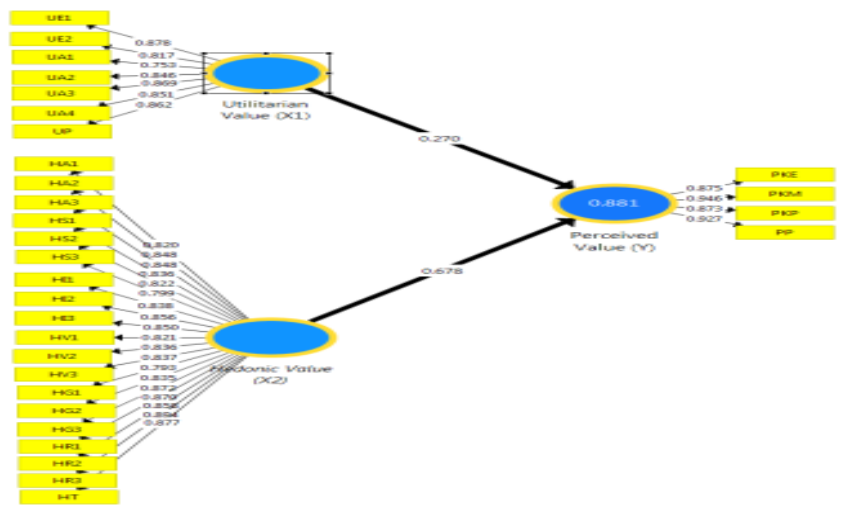

Fig. 1.Part Models

The picture above describes the testing of several variables that are interrelated, structural models is done to be able to see the results examined by the author. Therefore, to explain the variables being studied could be explained below as follows:

1. Constructs utilitarian value is measured using indicators UE1-UP. All indicators have factor loading values above 0.7 , AVE of commonality> 0.5 .

2. Constructs Hedonic value is measured using indicators HA1- HT. all indicators have factor loading values above 0.7 , AVE of commonality> 0.5 .

3. The construct of perceived value is measured using indicators PKE- PP. all indicators have factor loading values above 0.7 , AVE of commonality $>0.5$

In the table 3 shows the value of the variable outer loading utilitarian value (X1) with indicators of UE1-UP has a value of $>0.7$. This means that if the indicator in the test has a value of $>0.7$, it can be declared invalid.

TABLE I. THE OUTER LOADING UTILITARIAN VALUE (X1)

\begin{tabular}{|c|c|c|}
\hline Perceived Value & Loading Outer Value & Information \\
\hline PKE & 0875 & valid \\
\hline PKM & 0946 & valid \\
\hline PKP & 0873 & valid \\
\hline PP & 0927 & valid \\
\hline
\end{tabular}


In the table 4 shows the value of outer loading on the variable hedonic value (X2) with indicators of HA1-HT has a value of $>0.7$. This means that if the indicator in the test has a value of $>0.7$, it can be declared invalid.

TABLE II. OUTER LOADING HEDONIC VALUE (X2)

\begin{tabular}{|c|c|c|}
\hline Hedonic Value & $\begin{array}{c}\text { Loading Outer } \\
\text { Value }\end{array}$ & Information \\
\hline HA1 & 0820 & valid \\
\hline HA2 & 0848 & Valid \\
\hline HA3 & 0848 & Valid \\
\hline HS1 & 0836 & Valid \\
\hline HS2 & 0822 & Valid \\
\hline HS3 & 0799 & Valid \\
\hline HI1 & 0838 & Valid \\
\hline HI2 & 0856 & Valid \\
\hline HI3 & 0850 & Valid \\
\hline HV1 & 0821 & Valid \\
\hline HV2 & 0836 & Valid \\
\hline HV3 & 0837 & Valid \\
\hline HG1 & 0793 & Valid \\
\hline HG2 & 0835 & Valid \\
\hline HG3 & 0872 & Valid \\
\hline HR1 & 0870 & valid \\
\hline HR2 & 0858 & valid \\
\hline HR3 & 0894 & valid \\
\hline HT & 0877 & \\
\hline
\end{tabular}

TABLE III. OUTER LOADING PERCEIVED VALUE (X2)

\begin{tabular}{|c|c|c|}
\hline Utilitarian value & Loading Outer Value & Information \\
\hline UE1 & 0878 & valid \\
\hline UE2 & 0817 & valid \\
\hline UA1 & 0753 & valid \\
\hline UA2 & 0846 & valid \\
\hline UA3 & 0869 & valid \\
\hline UA4 & 0851 & valid \\
\hline UP & 0862 & valid \\
\hline
\end{tabular}

\section{Designing a Structural Model (Inner Model)}

TABLE IV. R SQUARE AND R SQUARE ADJUSTED

\begin{tabular}{|c|c|c|}
\hline Latent variables & R Square & R Square Adjusted \\
\hline$Y$ & 881 & \\
\hline
\end{tabular}

Table 4 the above table shows the $\mathrm{R}$ square obtained from the path algorithm model that has reliable and valid values. As for knowing the R2 value obtained from the square of the value of $\mathrm{R}$ square, namely:

\begin{tabular}{|ll|}
\hline $\mathrm{R} 2$ & $=0.881$ \\
& $=0.77$
\end{tabular}

On the results obtained $\mathrm{R} 2$ as much as value of 0.77 . The $\mathrm{R} 2$ is used to measure the rate of change of the independent variable on the dependent variable. The value obtained if the higher R2, the better the model predictions of the model dependent or research conducted. If the R2 value obtained by 0.77 then the dependent variable that can be explained by the independent variable is as many as $77 \%$ (excellent), while the remaining $23 \%$ are influenced by other factors outside the model being tested. However, R2 is not a major parameter in measuring the accuracy of the prediction model, but also has to pass a test of hypothesis. Due to the R-square test obtained are said to be very good and strong, it can perform bootstrapping or hypothesis testing.

\section{Hypothesis testing}

Hypothesis testing using t-test is used to see the effect of partially and $f$ test to see the effects simultaneously.

1. H1: There Utilitarian Value partially influence and significant to Woman Customer Perceived Value. This hypothesis is supported if the value of the Tstatistic greater than $\mathrm{T}$ table (1.96) and is not supported if otherwise. Based on the results boostraping can be seen that the T-statistic worth2.951, The results showed the T-statistic greater than $\mathrm{T}$ table (2.95> 1.96), it can be said thatThere Utilitarian Value partially influence and significant to Woman Customer Perceived Value, Based on the results of the analysis, the $\mathrm{H} 1$ proposed in this study received.

2. H2: There Hedonic Value partially influence and significant to Woman Customer Perceived Value. This hypothesis is supported if the value of the Tstatistic greater than $\mathrm{T}$ table (1.96) and is not supported if otherwise. Based on the results boostraping can be seen that the T-statistic is worth 7.567. The results showed the T-statistic greater than $\mathrm{T}$ table (7.56> 1.96), it can be said thatThere Hedonic Value partially influence and significant to Woman Customer Perceived Value, Based on the results of the analysis, the $\mathrm{H} 2$ proposed in this study received.

\section{$F$ test (simultaneous)}

In the use of partial least square (PLS) can process data in partial and simultaneously. For partial testing directly visible from the output data. However, for simultaneous testing is carried out by using a formula manually. F simultaneous test results can be seen in the table below

\begin{tabular}{|c|c|c|}
\hline TABLE V. CALCULATION OF F TABLE \\
\hline Degrees of Freedom & \multicolumn{2}{|c|}{ F table } \\
\hline DF1 (K-1) & 1 & \multirow{2}{*}{$\mathbf{3 , 8 7 3}$} \\
\hline DF2 (nK) & 298 & \\
\hline
\end{tabular}

Source: Research data processed

3. H3: There is the influence Utilitarian and Hedonic Value Value simultaneously and significantly Woman Customer Perceived Value.This hypothesis is supported if the value of $\mathrm{F}$ counts larger than $\mathrm{F}$ table with a significant level of $5 \%$, and is not supported if otherwise. Based on the calculated $\mathrm{F}$ test can be seen that $\mathrm{F}$ calculated is worth 2208 . The results showed $\mathrm{F}$ count larger than $\mathrm{F}$ table (3.873) then it can be said that there are significant Utilitarian and Hedonic Value simultaneously and significantly Woman Customer Perceived Value, Based on the results of the analysis, the $\mathrm{H} 3$ proposed in this study received

\section{Effect of Variable Utilitarian Value (X1) on Perceived Value (Y)}

Based on the results of hypothesis testing the influence of utilitarian value on perceived value, it can be concluded 
that (H1) significantly affects the perceived value of 2.865 . These results explain that the customer perceived value or perceived value can be enhanced by using the indicators contained in the utilitarian value that is the value of efficiency, the value of achievement and value price.

a. On the efficiency value that women prefer to shop at an online site if the site has a complete fashion products. It provides a great opportunity for female customers to choose the products they want. If a site does not have a complete product line so customers can only be transferred to the other sites. Then, for women who fast transaction process is essential to an online shop website. The transaction process can be easily its use to accommodate the shopping cart of groceries have been then process the payment, delivery and customer service response also included in the transaction process fast.

b. At achievement value when shopping at online sites is important for women to seek pre-planned items and find items they are looking for thus their shopping desires can be satisfied. This is consistent with reports from Nielsen Indonesia [17] recognize National Cup or online shopping day of the national states that the number of buyers on the online shopping sites by $56 \%$ the buyer has planned the products they want to buy and find previously.

c. Utilitarian value means focusing on the utility or value of the goods themselves, so for women who shop with a pattern of utilitarian value is also very important to compare prices on the site Lazada with other sites to see the corresponding price into the category of spending. So the price is also one of the most important values in the process of buying back or repurchases intention.

In the above explanation can we know that the motivation utilitarian a rational motive influenced by reason and rational view in the minds of consumers. From the research also shows that the value of the achievement is more dominant in the formation of utilitarian value. The results of this utilitarian value in line with the results of the[5] which mentions the existence of positive and significant impact on the value of utilitarian value of the perceived value.

\section{Effect of Variable Hedonic Value (X1) on Perceived Value (Y)}

Based on the results of hypothesis testing the effect of hedonic value on perceived value, it can be concluded that (H2) significantly affects the perceived value of 7.380 . These results explain that the perceived value of customers or perceived value can be enhanced by using the indicators contained in the hedonic value which is the value of adventure shopping, the value of social shopping, value the idea of shopping, value \ shopping, value gratification shopping, value the role of shopping, the value of trust.

a. On the women value shopping adventure assumes that view the products available on the website catalog, as well as the appearance of the website can stimulate them to buy or just look so that they can feel like an adventure or explore the range of products offered. As to that customer can find out the latest information about a product so as to make them interested in making a purchase. On average the research results of respondents said that shopping online is their hobbies so that the intensity of online shopping is certainly very great. This happens because in doing transactions online shopping can be done anywhere and can be done using any device. In a report from Nielsen Indonesia by [17] says that as many as $76 \%$ of people make the process of shopping online at home and $75 \%$ access by using a smartphone. For that, you can bet online shopping is the need of everyone and certainly for women. In the shop shopping adventure can be defined as a desire for excitement, adventure, and get a different environment [14].

b. On the social value of women shopping online shopping destination one of which is to be a socialite. The point is of course the women want to look attractive in front of friends or family so that they want to use an item that does not exist is sold in stores offline and in the end they make a purchase at the online site. when shopping at their online site will be sharing information about the product or online shopping with other people such as relatives or family and for those sharing the information can add to the shopping experience so that they are not wrong choosing not choose the wrong product and online sites.

c. On the value of the idea of shopping women argue that they shop online to follow fashion trends and fashion. As we can know that Lazada was ranked second in the survey results Indonesia TOP Brand 2017 in the category of fashion products (access from www.topbrand-award.com on the 04th of January, at 01:29). Women also found Lazada they visit the site to find new products that exist on the site. Thus, Lazada is a fitting place for the women to find and buy a fashion product that is a price that is affordable and full of fashion products offered. On the value of shopping idea is usually the women intend to do online shopping because of the emergence of a new trend about a product among women.

d. At value to shopping, women will shop online when they see their promotions about discounts, offer attractive prices, and promos. This usually happens when they learn a lot and know the schedule of a site will give the promo. The Promo can happen in a day or important dates such as the celebration of Christmas, New Year, Eid and other festivals. According to a report from Nielsen Indonesia about National Cup (national online shopping day) by [17] says that many of his customers by $80 \%$ pursue a discount or rebate when shopping than to get free postage, vouchers and cash back.

e. On the value of gratification shopping, the women found when they feel down mood and stress, they will shop online site Lazada back in. Tabloidbintang.com article published in 2016 about the lifestyles said in a research Journal of Consumer Research says that when a woman experiences stress and cope with the stress of shopping will not be lost even will grow because when women experience stress, they will shop stuff they do not need to pose a 
hedonic attitude. In this gratification values obtained by the consumer shopping experience to relax themselves, improve mood and mind.

f. In the role value shopping, women shopping on site Lazada to find and buy products to others. Because they think that to find the product you are looking for as a gift for their own pleasure. On reflection pleasure this value customer when they shop for other people so that they can feel positive feelings.

g. In the hedonic value, consumers also believe that trust is very important affect/influence to repurchase (repurchase intention). In this study the female consumers who shopped at an online site Lazada feel confident to the site.

The results of this study are also consistent with research conducted by Susanto and Andani [5] which showed that the hedonic value positive effect on perceived value.

The effect indicates that the higher the consumer internet hedonic shopping motivation, the higher the perceived value so that if the result of the higher perceived value that customers surely will repurchase (repurchase intention) is the key to an online store. As for the results of this study, the hedonic value which has a greater influence than the utilitarian. It is due to present someone who wanted to shop at an online site no longer see the value of the utility as a whole but rather, they are shopping for their offer of promotion more attractive than other sites, their sense of trust is at an online store, the influence of the social environment which can influence their purchasing decisions, their willingness to shop because they want to follow existing fashion trends, etc.

\section{Effect of Variable Utilitarian Value (X1) and Hedonic Value (X2) simultaneously on the Perceived Value (Y)}

Based on the results of hypothesis testing the influence of utilitarian value and hedonic value simultaneously to perceived value, it can be concluded that (H3) simultaneously have a significant effect on the perceived value. These results explain that the customer perceived value or perceived value can be influenced by the value of the internet shopping is utilitarian value and hedonic value. The value of the perceived value can also be considered in the formation of repurchase (repurchase intention) value the ease of transacting on the site Lazada, the security value in the form of protection of users' accounts, as well as the value of the ease of payment and delivery on site Lazada.

In this study are consistent with research conducted by [5] which suggested a positive effect simultaneously between utilitarian value and hedonic value. From this we can know to be able to make the customer repurchase (repurchase intention) it can be improved through the value of the internet shopping motivation (utilitarian value and hedonic value).

\section{CONCLUSIONS AND RECOMMENDATIONS}

The results of these studies showed significant results by using several test indicators value achievement, the value of efficiency, and the price value, the value of adventure shopping, social value shopping, the value of the idea of shopping, value $\backslash$ shopping, value gratification shopping, value the role of shopping, as well as the value trust. The samples of the study on 300 respondents were women in Batam eligible to be sampled. Based on the above results it can be concluded that the results of this study indicate that either partially or variables simultaneously utilitarian value (X1) and hedonic value (X2) positive and significant impact on the perceived value (Y).

Lazada online shopping sites need to make improvements and improved service through indicators variables utilitarian and hedonic shopping value. For example, by improving the appearance of online sites, increasing the speed of the shopping process, increasing consumer confidence, improving security and the delivery of products to customers shopping can repurchase (repurchase intention).

From the results of open-ended questions, the Researcher made in the questionnaires some message of the respondents said that they wanted Lazada Indonesia continues to improve existing services in terms of product offerings, prices up to offer free postage unlike some other online sites as well as the responsiveness of fast on customer service.

\section{Suggestion}

Lazada online shopping sites need to make improvements and improved service through indicators variables utilitarian and hedonic shopping value. For example, by improving the appearance of online sites, increasing the speed of the shopping process, increasing consumer confidence, improving security and the delivery of products to customers shopping can repurchase (repurchase intention).

From the results of open-ended questions, the Researcher made in the questionnaires some message of the respondents said that they wanted Lazada Indonesia continues to improve existing services in terms of product offerings, prices up to offer free postage unlike some other online sites as well as the responsiveness of fast on customer service.

\section{REFERENCES}

[1] www.Liputan6.com, 2017

[2] www.Topbrand-award.com, 2017.

[3] www.zahiraccounting.com, 2016.

[4] Kraft and Michael. A Look at Gender Differences and Marketing Implications. International Journal of Business and Social Science, Vol 3.2012

[5] Susanto, H., \& Andani, NF. Analisis Pengaruh Utilitarian Shopping Value dan Hedonic Shopping Value Terhadap Intent To Online Repurchase Dengan Peran Perceived Value Sebagai Mediator. Diponegoro Journal of Management, 1-12. 2015

[6] Kim, Xu, \& Gupta. Which is more important in internet shopping, perceived price or trust. Electronic Commerce Applications adn Research 11, 241-252.2012

[7] Utami, CW (2010). Manajemen Ritel. Jakarta: Four Salemba

[8] Ma'Ruf. (2006). Retail Marketing. Jakarta: Gramedia Pustaka Utama.

[9] Hanzaee, KH, \& Rezaeyeh, SP . Investigation Of The Effect Of Hedonic Value And Utilitarian Value On Customer Satisfaction And Behavioral Intentions. African Journal of Business Management, 7, 818-825.2013

[10] Ma'Ruf. (2006). Retail Marketing. Jakarta: Gramedia Pustaka Utama.

[11] Anderson, M., Palmblad, S., \& Prevedan, T. (2012). Atmospheric Effect On Hedonic And Utilitarian Customers. Linnaeus University.

[12] Kim and Yang. 2012. Mobile Shopping Motivation. International Journal of Retail \& Distribution Management, 40, 778-789.2012 
[13] Susanto, H., \& Andani, NF. Analisis Pengaruh Utilitarian Shopping Value dan Hedonic Shopping Value Terhadap Intent To Online Repurchase Dengan Peran Perceived Value Sebagai Mediator. Diponegoro Journal of Management, 1-12. 2015.

[14] Kim, Xu, \& Gupta.. Which is more important in internet shopping, perceived price or trust. Electronic Commerce Applications adn Research 11, 241-252.2012

[15] Sugiyono. Metode Penelitian Kuantitatif Kualitatif dan R\&B. Bandung: Alfabeta.2012

[16] Ghozali.Structural Equation Modeling. Semarang: Diponegoro University Publishers Agency .2011

[17] Sumantri. Hari Belanja Online Nasional. Indonesia Nielsen Company.2017 